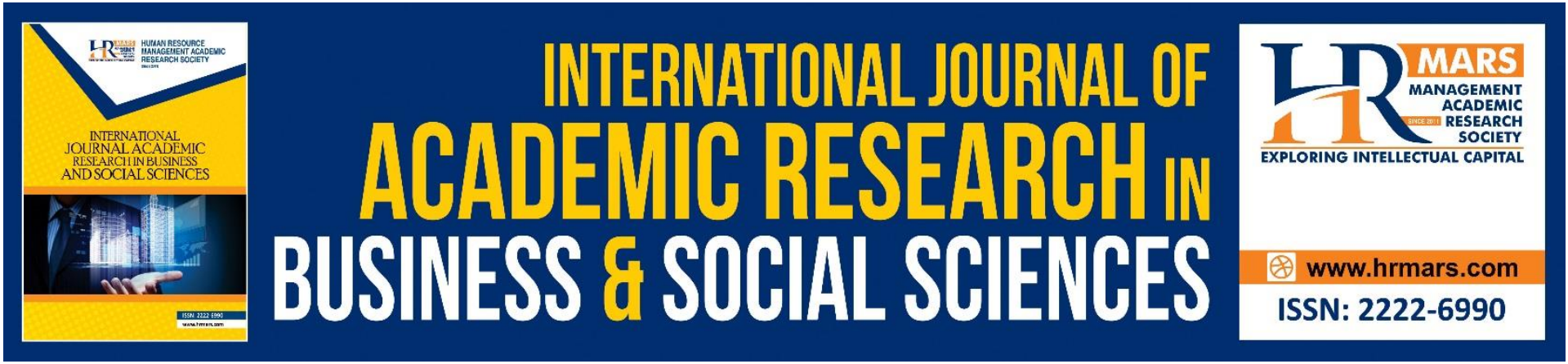

\title{
How the Mother Nurture the Children's Physical Potential?
}

\author{
Jamiah Manap, Salina Nen \& Norulhuda Sarnon
}

To Link this Article: http://dx.doi.org/10.6007/IJARBSS/v11-i6/10221

DOI:10.6007/IJARBSS/v11-i6/10221

Received: 13 April 2021, Revised: 16 May 2021, Accepted: 28 May 2021

Published Online: 15 June 2021

In-Text Citation: (Manap et al., 2021)

To Cite this Article: Manap, J., Nen, S., \& Sarnon, N. (2021). How the Mother Nurture the Children's Physical

Potential? International Journal of Academic Research in Business and Social Sciences, 11(6), 901-908.

Copyright: (C) 2021 The Author(s)

Published by Human Resource Management Academic Research Society (www.hrmars.com)

This article is published under the Creative Commons Attribution (CC BY 4.0) license. Anyone may reproduce, distribute, translate and create derivative works of this article (for both commercial and non-commercial purposes), subject to full attribution to the original publication and authors. The full terms of this license may be seen

at: http://creativecommons.org/licences/by/4.0/legalcode

Vol. 11, No. 6, 2021, Pg. 901- 908

http://hrmars.com/index.php/pages/detail/IJARBSS

JOURNAL HOMEPAGE

Full Terms \& Conditions of access and use can be found at http://hrmars.com/index.php/pages/detail/publication-ethics 


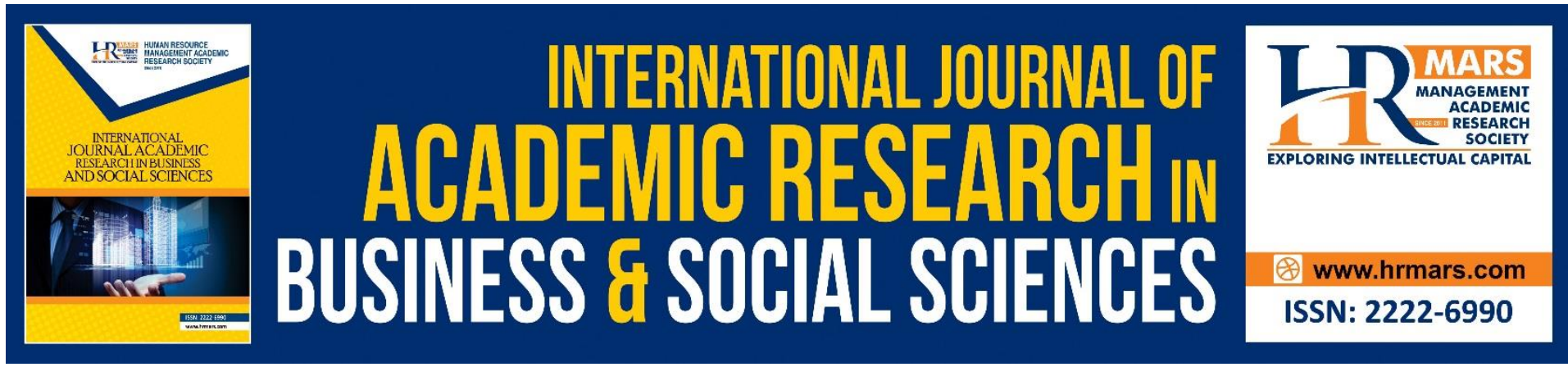

\title{
How the Mother Nurture the Children's Physical Potential?
}

\author{
Jamiah Manap, Salina Nen \& Norulhuda Sarnon \\ Center for Research in Psychology and Human Well-Being, Faculty of Social Science and \\ Humanities, The National University of Malaysia, 43600 Bangi, Selangor, Malaysia \\ Email: salina.nen@ukm.edu.my
}

\begin{abstract}
Physical growth and development are pertinent for every human being, especially in the early years. Thus, research was conducted to identify mother's effort towards developing their children's physical growth, using the main research question: How do mothers develop the physical potential among their children? In-depth interviews with four renowned mothers and their children were conducted to answer the research question. Finally, three major themes emerged: Trust, Physical Activities and Food. This finding could become a part of the parenting benchmark in nurturing the physical potential of children. Besides, more research should be done to explore the best practices of parents in nurturing their children.
\end{abstract}

Keywords: Parenting Skill, Physical Development, Exemplary Mother, Trust, Nutritious Food.

\section{Introduction}

Since in the womb, each child grows and develops rapidly rather than independently. However, in the early years, the child will depend on his parents to optimize the full potential of his physical development. Realizing the role of parents, particularly mothers to the proper upbringing and development of children, a national award named Ibu Mithali is given to the best Muslim mothers in Malaysia. The prestigious award has been in place since 1984 as a recognition of the mother's contribution to nation-building. All of the award winners have won the battle in the parenting arena as justified by their success story in nurturing their children. Thus, research was conducted to discover the true story behind the strength and determination of the exemplary mothers of Malaysia, also giving them a platform to share how they have optimized the physical development and potentials of their children.

\section{Literature Review}

\section{Parenting Skill}

Children are entrusted by Allāh to every parent (Ekram \& Mohamad, 2007). Thus, parenting skill is pertinent for each parent. Parenting skill is a particular ability in the process of promoting and supporting the physical, emotional, social, and intellectual development of a child from infancy to adulthood (Davies, 2000). According to Azis (2002), there are nine responsibilities that are quintessential for parents towards their offspring. 
The responsibilities include giving permissible sustenance (including food, clothes, shelter, health cost, living cost etc.), providing good childcare, breastfeeding for two years, offering a balanced and integrated education, bestowing children with good names, protecting the child from Satan through the call of 'adhān, 'iqāmah and good prayer upon birth, demonstrating gratefulness to Allāh through the act of 'aqiqah and extending charitable activities, treating the child with impartiality and love, and separating the boys and girls in different rooms to prevent incest.

\section{Parenting Skills for Physical Development}

After birth, it is highly recommended that mothers breastfeed their children for two whole years (Qur'ān, al-Baqarah: 233). This is because mother's milk contains complete and balanced nutrition for the baby (Rohani, 2002a). It also contains colostrum to strengthen the infant's antibody. It is also suggested that hugging and breastfeeding the baby within the first half an hour after giving birth will be very beneficial psychologically for both the mother and the baby. During the breastfeeding period, mothers should observe intake of sufficient and nutritious food, manage any negative emotions and avoid taking anti-pregnancy pills in order to ensure that the baby has enough milk for feeding. When the children grow up, parents should monitor their children and prevent them from taking any abusive substances such as drugs and liquor, or commit any acts which will cast them into destruction (Qur'ān, alBaqarah: 195). They should also prevent the children from wicked deeds such as homosexuality (Qur'ān, as-Shu'ara': 166) and fornication (Qur'ān, an-Nūr: 2) as they would obliterate the physical (biological) and spiritual development.

The children should be encouraged to involve actively in physical activities so that the cardiovascular system competency could be enhanced. This is also important to ensure that the child could oppose the adversary when needed or at least strike terror into their enemies' heart (Qur'ān, al-'Anfāl: 60). This will also serve as a preventive measure against being bullied by others. As parents, the father and mother are responsible to care for their children together even after divorce. The father is responsible to provide the alimony and clothing of the children, while the mother breastfeeds the child. The parents, however, are not forced to sacrifice themselves beyond limits (Qur'ān, al-Baqarah: 233). As the child grows, the middle childhood stage starts from six years old and continues until the age of 12 where the child's physical development is slower but stable and continuous. To allow for full development, they will need sufficient protein, carbohydrate, fat, vitamins and minerals (Mariani et al., 2008). Meanwhile, past research have reported an increasing number of people with obesity among adults which is due to sedentary lifestyle and unhealthy eating habit (Yu, 2011). There is a significant relationship between the level of parent-child interaction with the children's eating habit. Research also highlighted that parents are recommended to watch television together with their children and actively interact on the bad consumption of fast food advertisements while watching television.

\section{Research Method}

This research was conducted using the used qualitative research strategies in order to understand how the exemplary mothers, better known as Ibu Mithali nurture the physical potentials among their children. Ibu Mithali is a national award given to successful Malaysian Muslim. The main criteria of Ibu Mithali is having at least five successful children. However, in this research, most of the mothers have at least 9-17 successful children. Data was collected 
through a series of in-depth interviews with $I b u$ Mithali and their children. Besides, the research also uses document analysis and observation methods to support the research findings.

\section{Findings}

\section{Give Trust}

Madam Wan Mas trusts her children. She allows them to play football, go fishing and ride a bicycle with their friends. She has never imposed any limits on their physical activities. This is highlighted by her daughter in the interview:

She was confident with her children, for example when we were small, if (we) wanted to ride a bicycle, then we could go, if we fell, then we got back up again... we did what we wanted to do.

(Mrs. Nik Mastura, Former Educational Officer, Madam Wan Mas's daughter).

Another exemplary mother, Madam Maimon gave freedom for her children to make their own decisions and also express their opinion. The children even had the liberty to choose their life partners.

Let's say, if the children want to get married, she would not interfere...

(Mrs. Azizah, Former Headmistress, Late Madam Maimon's daughter).

Madam Maimon also allowed her children the freedom to select their course, future, and career. She listened to their opinion and did not force them to do something against their will. This is captured in the following interview excerpt:

Our mother respected and listened to our opinion and she would never force us. For example, when we applied for the course that we like, she did not object to it. Education too was the same situation. So did other matters, It meant that we have our own right...

(Dr. Aminah, Medical Doctor, Late Madam Maimon's daughter).

She also gave the children all the freedom in the world to choose their learning experiences and learning strategies. The children were allowed to do anything as long as they completed the tasks given first.

There was so much room for anything. I could do anything that I like, whether to study at the desk or reading the books lying in bed... she would not mind. As long as you do what you are supposed to do.

(Dr. Aminah, Medical Doctor, Late Madam Maimon's daughter).

\section{Encouraged Physical Activities}

Physical activities are necessary to enhance the children's cardiovascular system. This is because a sedentary lifestyle among teenagers will lead to obesity and an unhealthy body (Yu, 2011). An active lifestyle is also needed to enable the children to strike terror or stand against their opponents when attacked (Qur'ān, al-'Anfāl: 60). 
Based on the findings, all exemplary mothers or Ibu Mithāli always ensure that their children are active and fit. They encourage the children to play and get involved in physical activities especially in agriculture-related activities.

For example, Ustaz Ashraf and his brothers usually assisted their parents to prepare rice flour when they were children. Every evening, they would either play or follow their father to the farm.

If we want to eat the delicacies made from rice flour... the strongest child would be asked to do it. It was just like co-curriculum activities at school. If we were not playing soccer, there would be something else for us to be involved in... (Ustaz Ashraf, Lecturer, Madam Kalsum's son).

They usually helped their parents to work in the paddy field, fishing at the nearby river and planting fruits and vegetables.

I always worked at the paddy field... it became a routine... catching fish... planting watermelon...

(Ustaz Ashraf, Lecturer, Madam Kalsum's son).

Besides, Ustaz Ashraf and his siblings also walked to school every day.

I went to school... and came home walking... with Dato' Firdaus, we would walk.

(Ustaz Ashraf, Lecturer, Madam Kalsum's son).

Madam Esah's children also walked to school, about two miles away from their house.

Those in the secondary school would be walking home... Back then it was covered with thick forest and brick roads.

(Madam Esah, the 9th Ibu Mithālī).

Mrs Rosilah on the other hand went to school cycling with her cousin.

The village is far actually. I cycled along with three other friends, including my cousin...

(Mrs. Rosilah, Teacher, Madam Esah's daughter).

During the holiday, Madam Esah's son would help their father on the farm. She recalled, The boys would help out on the farm during the school holiday. But, not when the school was in session.

(Mrs. Rosilah, Teacher, Madam Esah's daughter).

The evening was the time for fun. Madam Esah would encourage her children to play after they have completed their homework. Playing is essential for children to gain competence in all areas of development (Gonzalez-Mena, 2006). Through playing, children will enhance their physical, social and cognitive skill and capability at a new level of mastery. This is consistent with Tong and friends (2009), finding that playing is an important indicator of children's social competence and intellectual development.

An excerpt from Mrs Rosilah highlights the play factor in childhood,

She gave us the freedom to play in the evening... at about five o'clock or so...

When it was not hot anymore, we played, after all of the homework was 
completed, she gave us freedom... Tok Esah's compound would be occupied with children when we were small... clamorous until Maghrib (dusk)...

(Mrs. Rosilah, Teacher, Madam Esah's daughter).

The children would be playing in the evening as the Qur'ān lesson was not conducted in the evening.

(Madam Esah, the 9th Ibu Mithālī).

She (Hajjah Zabedah) set the time for playing and learning.

(Jawiah, 2011).

Madam Wan Mas also allowed her daughter to climb trees and followed her husband to the forest even though this contradicted societal norm.

Nik Mastura admitted she was boyish in childhood because her parents allowed her to climb trees and wandered in the forest. She even followed her father to the forest for hunting and harvesting fruits from the forest.

(Safiah \& Rokiah, 2004).

\section{Food}

Food is the necessity of human being. Ibu Mithāli always ensures that their children receive sufficient and permissible food. This is essential as children need nutrients, balanced and healthy diet for optimum development (Mariani et al., 2010). As a matter of fact, it is important to observe good food intake especially during the maternity period up to the stage where the children become teenagers. Lack of nutrients will affect the physical and cognitive development of the children.

Mr Khairul, the son to one of the exemplary mothers recalled how his mother used to vigilantly ensure that her siblings eat good food,

She would insist that her children received nothing but good nutrition from the permissible source.

(Mr Khairul, Government Officer, Madam Alang Kamariah's son).

Ustaz Ashraf also believed that breastfeeding made them healthy. This is aligned with Allāh's command for mothers to breastfeed their children for two years (Qur'ān, al-Baqarah: 233). The milk from mothers is known to contain colostrum, complete and balanced nutrition, essential nutrients for infant's growth and development, also natural immunization (Rohani, 2008).

Breast-feeding is the factor and the reason that children rarely fall sick, (this is) because mother's milk contains immunization.

(Ustaz Ashraf, Lecturer, Madam Kalsum's son).

Madam Kalsum provided a fresh and balanced diet for her children. Indeed, rice, fresh vegetables, and fish supply us with sufficient carbohydrate, protein and vitamin for physical growth. Madam Kalsum's child enjoyed healthy servings during childhood,

Mom eats fish... saltwater fish, and a fishmonger would come to sell the fish.

For me, asam pedas, thick curry gravy cooked in the Northern style, and the one 
that has a kind of spicy condiment, salted fish, any types of fish, vegetables, all would be served...

Madam Wan Mas always served her children fish and fruits. Sometimes they would be served with poultry dishes.

Dish mainly fresh fish would always be there and sometimes, there would also be chicken and meat... and food was sufficient... these include fruits as well... (Mrs. Nik Mastura, Former Educational Officer, Madam Wan Mas's daughter).

While having meals, the mother would ensure that the meal for the children is a combination of the essential nutrients as prescribed in the food pyramid.

A plate of rice... a piece of chicken... each of us would be given one chicken... corn... beans... from our own farm...

(Madam Esah, the $9^{\text {th }} \mathrm{lbu}$ Mithālī).

Madam Awiah always prepared sufficient food for her children. She would never limit their food intake. The food contains a balanced and nutritious diet as depicted in the food pyramid: carbohydrate, protein and vitamins. All of her children are boys. Therefore, they needed calories for an active lifestyle.

I would normally cook in large quantities, (as I have) many children when it comes to food, I had never limit it, eating is ok, and took good care of it... no limitation on food for consumption... even now, I would ensure that everyone would get a piece of fish each, no sharing... If vegetables, it would take about two kilos daily... children, in the growing up phase love to eat. So I would cook not less than three dishes, all would be there, either fish, fried fish or chicken... (Madam Awiah, the $10^{\text {th }}$ Ibu Mithālī).

Based on the abovementioned excerpts, it can be deduced that all the exemplary mothers, better known as Ibu Mithāli's ensure that their children are served with food and nutrients that are sufficient for their physical and mental growth. Food security is defined as having physical and economic access to sufficient, safe and nutritious food to meet the dietary need and food preferences for an active and healthy life (Norhasmah, Zalilah \& Asnarulkhadi, 2010). Nutrients security is defined as adequate nutritional status in terms of protein, energy, micronutrients and minerals for all household members (Norhasmah, Zalilah \& Asnarulkhadi, 2010). This study shows that Ibu Mithālī' has performed their responsibilities as a good provider for both 'food security and 'nutrients security' to all their children to help them grow up into healthy teenagers and adults.

\section{Summary}

In conclusion, all the exemplary mothers or Ibu Mithāli in this study have initiated all efforts to develop the physical potential of their children. They gave trust, encouraged them to involve with physical activities and provide permissible and nutritious food to support their children's growth and development. Trust is important to build self-confidence, self-esteem and self-efficacy among children. Having trust means the children are free to grow naturally within their own passage of life. Meanwhile, children's involvement in physical activities is pertinent to refine gross and fine motor development and build a healthy and strong body. 
All exploration and physical activities need sufficient energy. Here, Ibu Mithali provides a balanced and healthy diet as the main source of energy to support the developmental task. Using these three formulae (trust, encouragement and food), all the Ibu Mithali have successfully developed their children's physical potential. Besides contributing to physical growth, the formula also serves to ensure the development of the children's social, spiritual and intellectual abilities.

\section{References}

Ekram, B., \& Mohamad, R. R. (2007). Parenting skills according to Qur'ān and sunnah, United States of America: Amana Publications.

Davies, M. (2000). The Blackwell Encyclopaedia of Social Work. United Kingdom: John Willey \& Sons.

Gonzales-Mena, J. (2006). The young child in the family and community. New Jersey: Pearson Merril Prentice Hall.

Jawiah, D. (2011). Ibu Mithālī ke-4: Hajjah Zabedah binti Haji Shahid (1918-1980) (The fourth exemplary mother: Hajjah Zabedah binti Haji Shahid (1918-1980)) in Siri dokumentasi MPWIM: Ibu Mithālī (MPWIM documentation series: Exemplary mother). Edited by Nik Safiah Nik Abdul Karim \& Noor Aziah Mohd Awal. Kuala Lumpur: Yayasan Dakwah Islamiah Malaysia.

Mariani, M., Mohamad, I. S., \& Adam, A. (2008). Kanak-kanak sekolah rendah (Secondary school children), in Keluarga, Kanak-kanak dan Remaja (Family, Children and Teenager), edited by Rozumah Baharudin and Rahimah Ibrahim, Serdang: Penerbit Universiti Putra Malaysia.

Safiah, N. A. K., \& Rokiah, T. (2004). Ibu Mithālī: Hajjah Wan Mas binti Wan Ibrahim (Exemplary mother: Hajjah Wan Mas binti Wan Ibrahim). Kuala Lumpur: Yayasan Dakwah Islamiah Malaysia.

Azis, N. P. (2002). Keluarga berdaya maju (Excel force family). Kuala Lumpur: Penerbit Universiti Malaya.

Norhasmah, S., Zalilah, M. S., \& Asnarulkhadi, A. S. (2010). Food security: Concept and definition. Journal of Community Health, 16 (2), 2-9.

Rohani, A. (2002). Keibubapaan pada peringkat pralahir dan kelahiran: Melindungi potensi zuriat, Parenting for prenatal and birth phase: Protecting offspring potential, in Keluarga dan Keibubapaan (Family and Parenting), edited by Jayaletchumi Mottan, Rohani Abdullah and Abdullah Al Hadi Muhammad. Serdang: Penerbit Universiti Putra Malaysia.

Tong, L., Shinohara, R., Sugisawa, Y., Tanaka, E., Maruyama, A., Sawada, Y., Ishi, I., \& Anme, T. (2009). Relationship of working mothers' parenting style and consistency to early childhood development: a longitudinal investigation. Journal of Advanced Nursing, 2067-2076. 